\title{
DIE ONTWIKKELING VAN DIE MENSLIKE BEWUSSYN: Ken Wilber SE AQAL-TeORIE
}

Author:

I.W. (Naas) Ferreira

\section{Affiliation:}

${ }^{1}$ Departement Praktiese

Teologie, Universiteit van

Pretoria, Suid-Afrika

\section{Correspondence to:}

I.W. (Naas) Ferreira

e-mail:

naasf@mweb.co.za

\section{Postal address:}

Posbus 12402, Elspark

1418, Suid-Afrika

\section{Keywords:}

psigoloog; mistikus;

Oosterse Filosofie;

godsdiens; grondbeginsels

\section{Dates:}

Received: 23 Apr. 2009

Accepted: 08 June 2009

Published: 19 Feb. 2010

How to cite this article: Ferreira, I.W., 2009, 'Die ontwikkeling van die menslike bewussyn: Ken Wilber se AQAL-teorie', HTS Teologiese Studies/ Theological Studies 66(1), Art. \#180, 8 pages. DOI: $10.4102 /$ hts.v66i1.180

This article is available at:

http:/ / www.hts.org.za

\section{Note:}

Hierdie artikel is ' $n$ verwerking van 'n deel van I.W. Ferreira se MThverhandeling getiteld 'Die relevansie van Ken Wilber se integrale ontwikkelingsteorie vir die pastoraat' onder studieleiding van prof. $\mathrm{dr}$ Yolanda Dreyer, voorgelê en aanvaar in Augustus 2008 deur die Departement

Praktiese Teologie,

Fakulteit Teologie,

Universiteit van Pretoria.

(C) 2010. The Authors. Licensee: OpenJournals Publishing. This work is licensed under the Creative Commons Attribution License.

\section{ABSTRACT}

The development of the human consciousness: Ken Wilber's AQAL theory

Kenneth Earl Wilber III, an integral philosopher, psychologist and mystic with an intelligence quotient of 160, was born on 31 January 1949 in Oklahoma City, Oklahoma, in the United States of America, and is considered by some as one of the most important philosophers of the 21st century. He developed his integral philosophy over 30 years, which can be divided into five phases. The most important aspects of his philosophy for the purposes of this article are the AQAL integral map of reality, and the evolution of consciousness. AQAL stands for 'all quadrants, all levels, lines and stages'. Wilber divides reality into singular and plural interiors and exteriors; or art, morals and science. Also deriving ideas from Developmental Psychology, he sees the evolution of consciousness unfolding in seven stages: archaic, magic, mythic, rational, pluralistic, holistic and transpersonal. This theory could add value to pastoral care by enabling pastors to support believers' own spiritual growth in pursuit of the kingdom of heaven.

\section{Biografiese agtergrond}

\section{INLEIDING}

Kenneth Earl Wilber II, 'n integrale filosoof, psigoloog en mistikus, is op 31 Januarie 1949 in Oklahoma City, Oklahoma, in Amerika gebore. Sy familiestamboom kan tot Meriwether Lewis (van die Lewis en Clark-ekspedisie) teruggevoer word. Kenneth Wilber senior was 'n hooggeagte lugmagkolonel wat gereeld van die een basis na die ander verplaas is. Volgens Brad Reynolds (2004:1), 'n student en kenner van Wilber en sy teorie, het Wilber 'n slag en liefde vir wetenskap gehad, maar eweneens vir sigarette, bier, partytiies en meisies, en het sy ouers hom oorreed om hom as mediese dokter te bekwaam. In 1967 skryf hy dus aan die Duke-universiteit in Durham, Noord-Carolina, in, maar slaan gou oor na Biochemie, en sit sy studie aan die Universiteit van Nebraska, Omaha, voort. In die laat sestigerjare was daar groot teenstand teen die Amerikaanse oorlog in Viëtnam, en dus het die Oosterse godsdienste groot byval by die naoorlogse generasie (die sogenaamde 'baby boomers') gevind. Dit is tóé dat Wilber die Chinese Taoïs Lao Tzu se boekie Tao te Ching (2007) onder oë gekry het.

Hierna het daar 'n lig vir Wilber opgegaan, en het hy alle dergelike leesstof wat hy in die hande kon kry behoorlik verorber, veral literatuur oor Oosterse Filosofie en godsdiens. Met 'n intelligensiekwosiënt van 160 lees Wilber maklik tussen twee en vier boeke per dag. Op universiteit het hy die Bhagavad Gita bestudeer in plaas van Chemie, en Kabbala in plaas van Kalkulus. Alan Watts, Zen, Krishnamurti, Vedanta, Goomaraswamy en Meester Eckhart was van sy ander gunstelinge. Wilber het ook Aldus Huxley se boek The perennial philosophy verken wat aanvoer dat dieselfde godsdienstige grondbeginsels in alle godsdienste voorkom. Dít het vir Wilber die deur na alle godsdienste oopgemaak. Wilber bestudeer dus die Psigologie van Carl Jung, Abraham Maslow, Stanislav Grof en Jean Piaget, sowel as Westerse Filosofie. Kort daarna begin Wilber met gereelde Zen- Boeddhistiese meditasie, baiemaal saam met die Amerikaanse Zen-meester Philip Kapleau, en lees hy Sri Ramana Maharshi, Kirpal Singh en Adi Da. Reynolds sonder een besondere invloed op Wilber gedurende die sewentigerjare uit:

However, the evolutionary theorist who exerted the most influence on Wilber at this time was the great synthesizer of Eastern philosophy and Western science, Sri Aurobindo, especially his incomparable magnum opus "The life divine" (1939, 1965). (Die res van hierdie gedeelte steun op Reynolds, tensy anders vermeld.)

(Reynolds 2004:9)

Hoewel Wilber 'n Boeddhis genoem word, beweer hy dat hy sterk bande met Vedanta-Hindoeïsme en Christelike mistisisme het, maar dat elke mens tog ' $n$ tradisie moet volg. Wilber is dus deur baie denkers en godsdienste beïnvloed.

Wilber se oeuvre ontwikkel oor dertig jaar en vyf fases; hy is tans in die vyfde. Die eerste fase strek van 1972 tot 1978 waarin hy twee boeke skryf: The Spectrum of Consciousness (1977) en No Boundary: Eastern and Western approaches to personal growth (1979). Wilber was 23 jaar oud toe hy The Spectrum of Consciousness voltooi het, maar moes vyf jaar wag voordat ' $n$ uitgewer daarin belang gestel het. Die boek is allerweë lof toegeswaai as die eerste sintese tussen Westerse en Oosterse Psigologie. In dié tyd huldig Wilber nog die romantiese siening dat daar van die onderbewuste na die selfbewuste na die superbewuste beweeg word, oftewel van die id na die ego na God. Die hoogste punt van dié spektrum is vir die romantici ' $n$ terugkeer na, of 'n herontdekking van, oorspronklike dog verlore potensiaal. Nie lank ná Wilber se eerste boek nie is No Boundary gepubliseer, en het uitnodigings om referate by kongresse te lewer begin instroom.

Wilber het egter verkies om aan te hou werk om sy idees te verbeter en telkens iets nuuts te kan bydra. Hy het sy meditasie verdiep, en het die stadium van verligting ('enlightenment') bereik. Die begrippe wat mistici gebruik het, was nie meer vir Wilber vreemd nie omdat hy dit self beleef het. Volgens Reynolds (2004:19) berus Wilber se filosofie op 'integral transformative practice'. Wilber het op ' $n$ ontdekkingstog van die gebied van die subtiele (die verstand en siel) gegaan, en het die regte leiding uit die boeke van die moderne Sufi-mistiek-jogi Kirpal Singh gekry. Teen 1978 het Wilber se meditasie 
gekonsentreer op wat Reynolds (2004:20) 'the nature of the self, or finding the witness, the causal consciousness behind all experiences' noem. Mistici beskou dít as die kernpunt van bestaan. Wilber self beskryf dié fase soos volg:

So "soul" is both the highest level of individual growth we can achieve, and also the final barrier, the final knot, to complete enlightenment or supreme identity, simply because as transcendental witness it stands back from everything it witnesses. (Wilber 2000c:460)

Wilber het derhalwe satori (geestelike insig) of kensho bereik wat ook sy lees- en skryfwerk beïnvloed het. Hy beskryf dus die uiteindelike, allerhoogste staat van bewussyn (die 'ultimate state of consciousness') uit persoonlike ervaring (Wilber 2001:126144 ), en beveel ook geestelike oefeninge by sy lesers aan om hulle te help om na die siel te reik.

Gedurende die tweede fase (1978-1983) verskyn The Atman Project: A transpersonal view of human development (1980), Up from Eden: A transpersonal view of human evolution (1995), A Sociable God: Towards a new understanding of religion (1983) en Eye to Eye: The quest for the new paradigm (1983). Die oorgang tussen die eerste en tweede fase het ontstaan toe Wilber in The Atman Project en Up from Eden probeer het om sy romantiese teorieë verder uit te werk. Hy het reeds ' $\mathrm{n}$ aantal hoofstukke van The Atman Project in die tydskrif ReVision gepubliseer toe hy sy fout agterkom. Romantici beskou die hoogste of transpersoonlike vlak as ' $n$ terugkeer na die eerste of pre-persoonlike fase. Wilber skryf dus ' $n$ aantal artikels oor die sogenaamde pre/trans-drogrede om dié fout uit te wys. Omdat die pre- en transpersoonlike, of die pre- en transrasionele, nie rasioneel is nie, is dit maklik om dié twee te verwar. Met The Atman project konsentreer Wilber op individuele ontwikkeling (ontogenie), en met Up from Eden op die gesamentlike evolusie van die mensdom (filogenie). Terwyl die Bybel die tuin van Eden as die paradys beskou, begryp Wilber dit as die begin van die ontwikkeling, en daarom heet sy vierde boek Up from Eden. Atman is 'n mistiese Hindoe-begrip, en volgens Teasdale maak mistici slegs met Brahmaan of God kontak deur hoër state van meditasie:

[w]hich then opens the way to inner awareness of the self, or Atman, the immanent presence of the Brahman within all beings and every particle of reality. Atman is Brahman, and Brahman is Atman. They aren't concepts but pure mystical realization.

(Teasdale 1999:52)

Met Wilber se volgende boek, A Sociable God: A brief introduction to a transcendental Sociology, sien hy af van transpersoonlike psigologie, aangesien hy na iets omvattender, 'n integrale volledige-spektrummodel, op soek was.

In die derde fase (1983-1994) word Transformations of Consciousness (1986) en Grace and Grit (1991) gepubliseer. Reynolds (2004:15) noem dié fase 'The Integral Vision: Self, Levels \& Lines'. Wilber was intussen op soek na 'n nuwe paradigma. Toe hy op 26 November 1983 met sy tweede vrou en sielsgenoot, Treya Killam, trou was hy ' $\mathrm{n}$ self-erkende Zenmonnik met net ' $\mathrm{n}$ tikmasjien, tafel, stoel en 4000 boeke op sy naam. Treya sou vyf jaar later aan kanker sterf. Ná Treya se dood publiseer Wilber Grace and Grit, 'n emosionele/spirituele leeservaring.

Die vierde fase breek ná Treya se dood aan (1995-2000) en lewer sy meesterwerk, Sex, Ecology, Spirituality: The Spirit of evolution (1995), op, sowel as A Brief History of Everything (1996), The Eye of Spirit: An integral vision for a world gone slightly mad (1997), The Marriage of Sense and Soul: Integrating science and religion (1998), One Taste: The journals of Ken Wilber (1999), The Collected Works of Ken Wilber, Volume 1-4 (1999), The Collected Works of Ken Wilber, Volume 5-8 (2000), Integral Psychology: Consciousness, Sprit, psychology, therapy (2000), en A Theory of Everything: An integral vision for business, politics, science and spirituality (2000). Ná Grace and Grit het Wilber tien jaar lank niks geskryf nie. Drie jaar daarvan het hy as ' $n$ kluisenaar geleef, en met net vier mense kontak gehad. Hy het gelees, gemediteer, en sy gedagtes agtermekaar gekry. Wilber het tot 200 ontwikkelingsmodelle langs mekaar geplaas om patrone te probeer uitwys. Dit is eers toe hy sien dat sommige met interne aspekte werk, en ander weer met eksterne aspekte; sommige met enkelvoudige, en ander met meervoudige perspektiewe; dat die kwadrant-gedagte by hom posgevat het. Met Sex, Ecology, Spirituality formuleer Wilber die eerste keer sy kennis van modelle en spirituele ontwikkeling in ' $n$ integrale model. Sy daaropvolgende boeke bou hierop voort. In 1999 en 2000 word sy versamelde werke in agt volumes gepubliseer - iets buitengewoons in die publikasiewêreld. In 2000 stig Wilber ook die Integral Institute of I-I wat daarop gemik is om die integrale visie op alle terreine van die samelewing toe te pas.

Gedurende die vyfde fase (2000 tot op hede) begin Wilber sy integrale teorie in die openbare domein bekend stel. Boomeritis: A novel that will set you free (2002), Integral Spirituality: A startling new role for religion in the modern and postmodern world (2006), The Integral Vision: A very short introduction to the revolutionary integral approach to life, God, the universe and everything (2007), en Integral Life Practice (2008) het tot op hede in dié fase verskyn. Wilber woon tans in die Amerikaanse stad Denver in Colorado.

Dit is duidelik dat die eerste drie fases Wilber op die integrale teorie van sy vierde en vyfde fase voorberei het, waarin hy die innerlike en die uiterlike, en die enkelvoud en meervoud met mekaar kon verbind, en uiteindelik die akroniem AQAL vir sy integrale model begin gebruik. Die integrale of AQAL-filosofie staan krities teenoor pluralistiese relativisme en subjektiewe narcissisme, waarmee die akademiese wêreld en New Ageteorieë volgens Reynolds (2004:64) deurspek is. Hierdie studie sal meesal op die vierde en vyfde fase konsentreer, en sal waar van toepassing ook na ander werke verwys.

\section{KEN WILBER SE TEORIE}

\section{Inleiding}

Hierdie bespreking word tot daardie elemente beperk wat nodig is om Wilber se teorie te verstaan, en wat op die pastoraat betrekking het. Selfs ' $n$ opsomming van Wilber se werk is kompleks. Daar ís egter ' $n$ aantal aspekte wat vir hierdie studie van belang is. Die eerste is die beweging na God, oftewel die ontwikkeling van die bewussyn.

Die idee van die trapleer op na die Gees, of soos Wilber dit deesdae noem, die vervoerband, kom van Plato na aanleiding van die volgende uitlating deur Alfred North Whitehead (Wilber 2000b:329): 'The safest general characteristic of the whole Western philosophical tradition is that it consists of a series of footnotes to Plato.' Die reis na Bo is derhalwe ook die weg na Onder. Plato het twee duidelike bewegings met betrekking tot die Gees geïdentifiseer:

The first movement is a descent ${ }^{1}$ of the One into the world of Many, a movement that actually creates the world of Many, blesses the Many and confers Goodness on all of it: Spirit immanent in the world. The other is the movement of return or ascent from the Many to the One, a process of remembering or recollecting the Good: Spirit transcendent to the world.

(Wilber 2000b:330)

Dít is die pad wat al die nadenkende (mistieke) godsdienste volg - die gelowige beweeg na God, die 'Gans Andere', die Gees. Arthur Lovejoy som dit soos volg op:

...[h]aving arrived at the conception of a pure alien to all the categories of ordinary thought and in need of nothing external to itself, he forthwith finds in just this transcendent and absolute Being the necessitating ground of this world; and he does not stop short of the assertion of the necessity and worth of the existence of all conceivable kinds of finite, temporal, imperfect, and corporeal beings.

(Lovejoy 1964:45)

1.Alle beklemtonings in oorspronklike bronne is die van die oorspronklike outeurs. 
Die pad na Bo is die pad van die Goeie; die pad na Onder is die pad van Goedheid. Wilber (2000b:337) voer aan dat 'n mens by alle mistieke tradisies wat die pad na Bo en Onder integreer en verenig dieselfde soort temas vind: 'The Many returning to and embracing the One is Good, and is known as wisdom; the One returning to and embracing the Many is Goodness, and is known as compassion.' Maar as wysheid die 'Baie' in die 'Een' sien, weet barmhartigheid dat die 'Een' in die 'Baie' is, en dat die 'Een' boonop gelyk in elke wese teenwoordig is. Wilber stel dit só:

...[a]nd so each is to be treated with compassion and care, not in any condescending fashion, but rather because each being, exactly as it is, is a perfect manifestation of Spirit.

(Wilber 2000b:337)

Dit is eers wanneer die pastor elke wese, ongeag sy/haar ontwikkelingsvlak, as die perfekte openbaring van God beskou, dat pastorale ontferming in werking sal tree om gelowiges na hoër strukture te kan begelei. Die integrasie van die twee paaie is vir die pastoraat belangrik, aangesien die gelowige se pad na God die gevolg is van God se betrokkenheid by die mens. Die mistikus, die een wat reeds eenwording beleef het, word dus hierdeur teruggestuur om barmhartigheid aan almal te gaan bewys. Dorothee Soelle som dit só op:

My questioning is focused on social reality. This means that for the sake of what is within, I seek to erase the distinction between a mystical internal and a political external. Everything that is within needs to be externalized so it doesn't spoil, like the manna in the desert that was hoarded for future consumption.

(Rumscheidt 2001:3)

'n Ander belangrike aspek is dat alles - elke gebeurtenis, mens en groep - altyd déél is van die geheel, en nooit nét die geheel is nie. Wilber gebruik Arthur Koestler se term 'holon' om hierdie begrip te beskryf, en wys daarop dat wanneer iets van een vlak na die volgende vlak beweeg, dit die vorige vlak transendeer (agterlaat), maar dit terselfdertyd inkorporeer (binnelaat). ' $\mathrm{n}$ Atoom is altyd deel van 'n sel; die sel is deel van 'n weefsel; en die weefsel is deel van ' $n$ ledemaat, wat op sy beurt deel is van ' $n$ liggaam. Wanneer ' $n$ holon egter dink dat dit op sigself die geheel is, ontstaan daar moeilikheid. Wilber (2000c:485) verduidelik dit soos volg: 'An arrogant Holon doesn't want to be both the whole and a part; it wants to be a whole, period...Power replaces communion; domination replaces communication; oppression replaces reciprocity.' Hierdie holon, wat die vorige vlakke transendeer én inkorporeer, is ' $n$ verbetering op Nolte (2007:15) wat beweer " $n$ nuwe paradigma is nie ' $n$ kombinasie uit vorige en nuwe paradigmas nie, maar ' $n$ breuk met interpreterende raamwerke van vroeër'. Postmoderniteit is nie ' $\mathrm{n}$ totale afstanddoening van moderniteit nie - dit herken die strukture van moderniteit, maar voer aan dat daar ander strukture en paradigmas is wat ewe veel gewig dra. Wilber betoog soos volg:

The disaster of modernity was that it reduced all introspective and interpretative knowledge to exterior and empirical flatland: it attempted to erase the richness of interpretation from the script of the world... One of the great and noble aims of postmodernism was to introduce interpretation as an intrinsic aspect of the Kosmos.

(Wilber 2000d:184)

Postmoderniteit is dus nie ' $n$ algehele afsiening van moderniteit soos Nolte dit wil hê nie, maar wel 'n byvoeging tot en uitbouing daarvan.

Nóg ' $n$ belangrike saak is dat hoër strukture deur laer vlakke oorgeneem kan word:

Tribalism, when left to its own devices, is relatively benign, simply because its means and its technologies are relatively harmless... The problem is that the advanced technologies of rationalization, when hijacked by tribalism and its ethnocentric drives, can be devastating.

(Wilber 2000c:486)
Ons sien dit by Iran wat kernwapens wil ontwikkel, maar wie se bepaalde vorm van Islam op die mitologiese vlak impliseer dat hulle slegs wapens van 2000 jaar of langer terug mag besit. Ook Afrika, wat stamgerig is, het toegang tot moderne wapens om volksmoorde mee te pleeg.

\section{Wilber se 'drie hoofstrome van die self'}

Volgens Reynolds (2006:199-202) is een van die ophelderings wat Wilber se AQAL-teorie gebring het die 'drie hoofselflyne' of die 'drie hoofstrome van die self' - dit wat Wilber die frontale ego (ego), die dieper psige (siel), en die Getuie (oorsaaklike/ kousale Self) noem. Hierdie drie strome stem ook met die drie hoofdomeine van die algemene/gros (materie en liggaam), die subtiele (verstand en siel), en die oorsaaklike (vormlose gees) ooreen, wat algemeen deur die groot wysheidstradisies erken word.

\section{Frontale lyn/ego/egoïstiese Self}

Hierdie hooflyn van die aparte Self, of die 'ego-ek', word in die naaste Self (of 'Ek') en die verste Self ('my') onderverdeel. Die naaste Self is die kern waaruit mense die lewe ervaar, en die verste Self die deel van die Self wat die 'Ek' kan waarneem. Daarom is die frontale lyn van die Self, wat deur die ontwikkelende transformasies ontvou, by die evolusie van die bewussyn betrokke. Hieroor het Wilber (2000e:126) die volgende te sê:

The frontal includes all of the self-stages that orient consciousness to the gross realm (the material self, the bodyself, the persona, the ego, and the centaur - all of which can be generically called "the ego").

(Wilber 2000e:126)

Die frontale is die Self wat op die algemene lyn van kenvermoë staatmaak, en daarom is dié Self-stroom vir bewussynsoriëntering in en bewussynsintegrasie by die algemene domein verantwoordelik.

\section{Dieper psige/siel/outentieke Self}

Hierdie is die aspek van die Self wat die frontale persoonlikheid en ego transendeer, maar tog sy eie ontwikkelingstrajek volg. Wilber (2000e:126) beweer dat die siel of dieper-psige-lyn al die Self-strome insluit wat die bewussyn by die verskillende fasette van die subtiele sfeer laat aanpas:

The soul is the self that depends on the subtle line of cognition (which includes, imagination, reverie, daydreams, creative visions, hypnogogic states, etheric states, visionary revelations, hypnotic states, transcendental illuminations).

(Wilber 2000e:126)

Daarom is die siel die Self-stroom wat vir bewussynsoriëntering in en bewussynsintegrasie by die subtiele arena verantwoordelik is.

\section{Getuie/Self/(Atman)/Absolute Self}

Die transendentale Self of Getuie ontwikkel nie op sigself nie, aangesien dit pure vormloosheid is. Volgens Wilber (2000e:258, nota 24) is dit die toegang tot die Self wat ontwikkel. Die ware aard van die Self (Atman), wat eindelik transendentaal en vormloos is, is 'die Getuie' (synde bewussyn self) van alle moontlike vorme. Die Getuie is die Self wat op die kousale lyn van kenvermoë staatmaak (die vermoë om te fokus; om op 'n afstand getuie te wees) en is dus die Self wat vir bewussynsoriëntering in en bewussynsintegrasie by die kousale/oorsaaklike domein verantwoordelik is. Volgens Wilber (2000e:127) is dit hierdie Self wat vir die oorkoepelende integrasie van al die ander Selwe, golwe en strome verantwoordelik is: 'And it is the Self supreme that prevents the three realms - gross, subtle, and causal - from flying apart in the first place.

Die Selfsisteem in figuur 1 hier onder (Reynolds 2006:199-202) is ' $n$ opsomming van die interne enkelvoudsperspektief. Wilber noem dit 'One Taste', wat die hoogste ontwikkelingservaring verteenwoordig: 
The moment this constant nondual consciousness is obvious in your case, a new destiny will awaken in the midst of the manifest world. You will have discovered your own Buddha Mind, your own Godhead, your own formless, spaceless, timeless, infinite Emptiness, your own Atman that is Brahman, your Keter, Christ consciousness, radiant Shekhinah - in so many words, One Taste.

(Wilber 2000d:343)

Die bewussynspektrum aan die regterkant van die figuur wys op die pre-persoonlike ontwikkeling vanaf materie na liggaam, die persoonlike ontwikkeling van vroeë denke en volwasse verstand, en die psigiese, subtiele en kousale ontwikkeling wat as transpersoonlik bestempel word. Die onderste lyn verteenwoordig die algemene (hierdie lewe), die subtiele (tussen lewens), en die kousale (ongebore) niedualistiese goddelike grondslag. Uit die algemene kom die frontale lyn van die ego waarin die naaste, die kern- en die verste Self voorkom. Uit die subtiele kom die dieper psige wat na die siel lei, terwyl die Getuie en Atman, wat ook die niedualistiese goddelike doel verteenwoordig, uit die kousale ongebore spruit.

In sy werk gaan Wilber (2001:180-220) ook op een van die foute van die godsdiens, psigologie en antropologie in, naamlik om die hoër vlakke met die laer vlakke, of die laer vlakke met die hoër vlakke te verwar. Volgens Wilber (2001:180) is dié fout, wat hy die pre/trans-drogrede noem, maklik om te verduidelik. Die veronderstelling is dat alle mense toegang het tot drie algemene gebiede van bestaan en kennis, naamlik die sensoriese, die verstandelike en die geestelike. Hierdie domeine word op verskillende maniere geopenbaar - as die onderbewuste, die selfbewuste en die superbewuste; as prerasioneel, rasioneel en transrasioneel; of as pre-persoonlik, persoonlik en transpersoonlik. Wilber stel die punt dat aangesien die prerasionele en die transrasionele albei nierasioneel is, dit vir die oningeligte maklik identies kan voorkom.

\section{Die Selfsisteem}

Sommige 'verlaag' (reduseer) die mistieke tot die prerasionele. Ná Ellen T. Amour (2006:45) se uiteensetting van Middeleeuse mistici - die sogenaamde 'premoderne denkers' - se direkte mistieke eenwordings met God, troos sy haar postmoderne lesers: 'I am not advocating that we somehow turn the theological clock backward and re-enter a premodern mindset.'Wilber (2000b:212) beskou Freud as' $n$ reduseerder, en Jung as ' $n$ verheffer, en erken dat albei half reg én half verkeerd is:

A good deal of neurosis is indeed a fixation/regression to prerational states, states that are not to be glorified. On the other hand, mystical states do indeed exist, beyond (not beneath) rationality and those states are not to be reduced.

(Wilber 2000b:212)

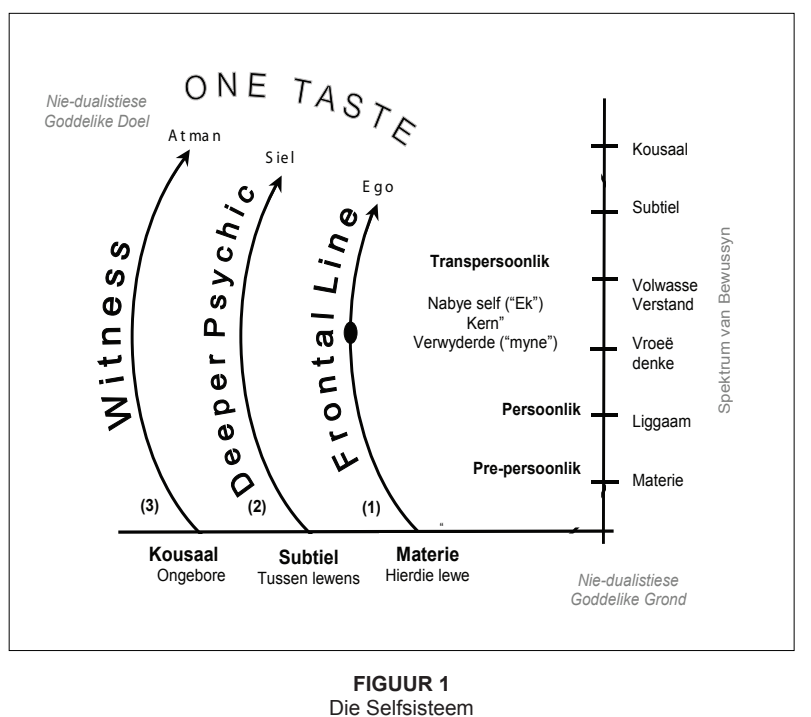

\section{Wilber se kwadrante}

Wilber se grootste bydrae is egter sy kaart van die werklikheid. In sy werk het Wilber agtergekom dat die navorsing oor menslike ontwikkeling in vier dele verdeel kan word: ' $n$ interne enkelvoud en meervoud, en ' $n$ eksterne enkelvoud en meervoud (sien figuur 2 hier onder). Wilber (2000f:51) noem die kwadrant links bo op die kaart die eerstepersoon- (interne) enkelvoud, of 'die ek'-ontwikkeling. Dit konsentreer op die fenomenologiese en strukturele aspekte van die ontwikkeling van die mens se individuele bewussyn. Die interne meervoud (die kwadrant links onder), oftewel 'die Ons', konsentreer op die kultuur en groep se etiese ontwikkeling, en dus die hermeneutiese aspekte van die menslike bewussyn. Regs bo is die individuele eksterne (die eksterne enkelvoud) wat die sigbare optrede en aspekte van die individu, oftewel 'die dit', ondersoek, terwyl die kwadrant regs onder (die eksterne meervoud) die sosiale aspekte van die mensdom, oftewel 'die ditte', verteenwoordig.

Wilber (2000f:51) deel die navorsers wat aan die verskillende kwadrante gewerk het soos volg in: Die navorsers in die individuele linkerkantse subjektiewe kwadrant is Sigmund Freud, Carl Jung, Jean Piaget, Sri Aurobindo, Plotinus en Gautama Boeddha. In die kollektiewe linkerkantse subjektiewe kwadrant is navorsers soos Thomas Kuhn, Wilhelm Dilthey, Jean Gebser, Max Weber en Hans-Georg Gadamer. Wilber (2000f:50) beskryf hierdie kwadrant se fokuspunte soos volg: 'These shared values, perceptions, meanings, semantic habits, cultural practices, ethics and so on, I simply refer to as culture, or the intersubjective patterns in consciousness.'

Die linkerkantse subjektiewe kwadrant, wat die interne enkelvoud verteenwoordig, is die ontwikkeling van die enkeling se binneste - van die instinktiewe, magiese, egosentriese, mitiese, rasionele, pluralistiese, holistiese tot die niedualistiese vlakke. Die linkerkantse kollektiewe kwadrant, wat die interne meervoud verteenwoordig, dui op die kulturele/morele ontwikkelingsvlak. Dit is argaïes, animisties-magies, mities, wetenskaplik-rasioneel, pluralisties, holisties tot geïntegreerd, en intersubjektief. Hierdie studie fokus op die linkerkant in sy geheel, en in besonder op die interne persoonlike enkelvoud, oftewel 'die ek'.

Volgens Wilber (2000f:50) het hierdie intersubjektiewe patrone objektiewe korrelate wat empiries nagevors kan word. Die kollektiewe uitwendige kwadrant (die eksterne meervoud) is die sosiale strukture van oorlewingstamme, etniese groepe, feodale ryke, vroeë nasies, korporatistiese state, waardegemeenskappe, en holistiese en geïntegreerde groepe. Navorsers op dié gebied van Sisteme Teorie is, Talcott Parsons, August Comte, Karl Marx, Gehard Lenski en die ekologiese Web van die Lewe. Wilber noem dit die 'sosiale sisteem'. Die eksterne individuele kwadrant (die eksterne enkelvoud) verteenwoordig die uiterlike fisieke ontwikkeling van die individu. Navorsers en teoretici in dié kwadrant is BF Skinner, John Watson, John Locke, en diegene op die gebied van die empirisme, behaviorisme, Fisika, Biologie, Neurologie, ensovoorts.

Dit is belangrik om daarop te let dat die vlakke, sowel binne as buite, en sowel individueel as kollektief, in die vier kwadrante met mekaar korreleer. Iemand in die interne individuele kwadrant op die mitiese vlak se moraliteit sal deur die e tiek van die premoderne mitiese orde bepaal word, wat ekstern deur die sosiale bestel en die landbou en tuinbou van die vroeë nasies verteenwoordig word. Hoe hoër die individu se ontwikkeling, hoe kleiner word die groep, maar hoe meer die perspektiewe waartoe die persoon in staat is. Dit beweeg van egosentries, na etnosentries, na wêreldsentries, na kosmosentries (Wilber 2007:51). Elke mens begin by die onderste blokkie, en beweeg dan boontoe. Dit is ook die ontwikkelingsroete wat die mensdom in sy geheel tot op hede gevolg het.

\section{Wilber se ontwikkelingsvlakke}

Die invloed wat Wilber se geheelbeeld (AQAL) op godsdiens kan 


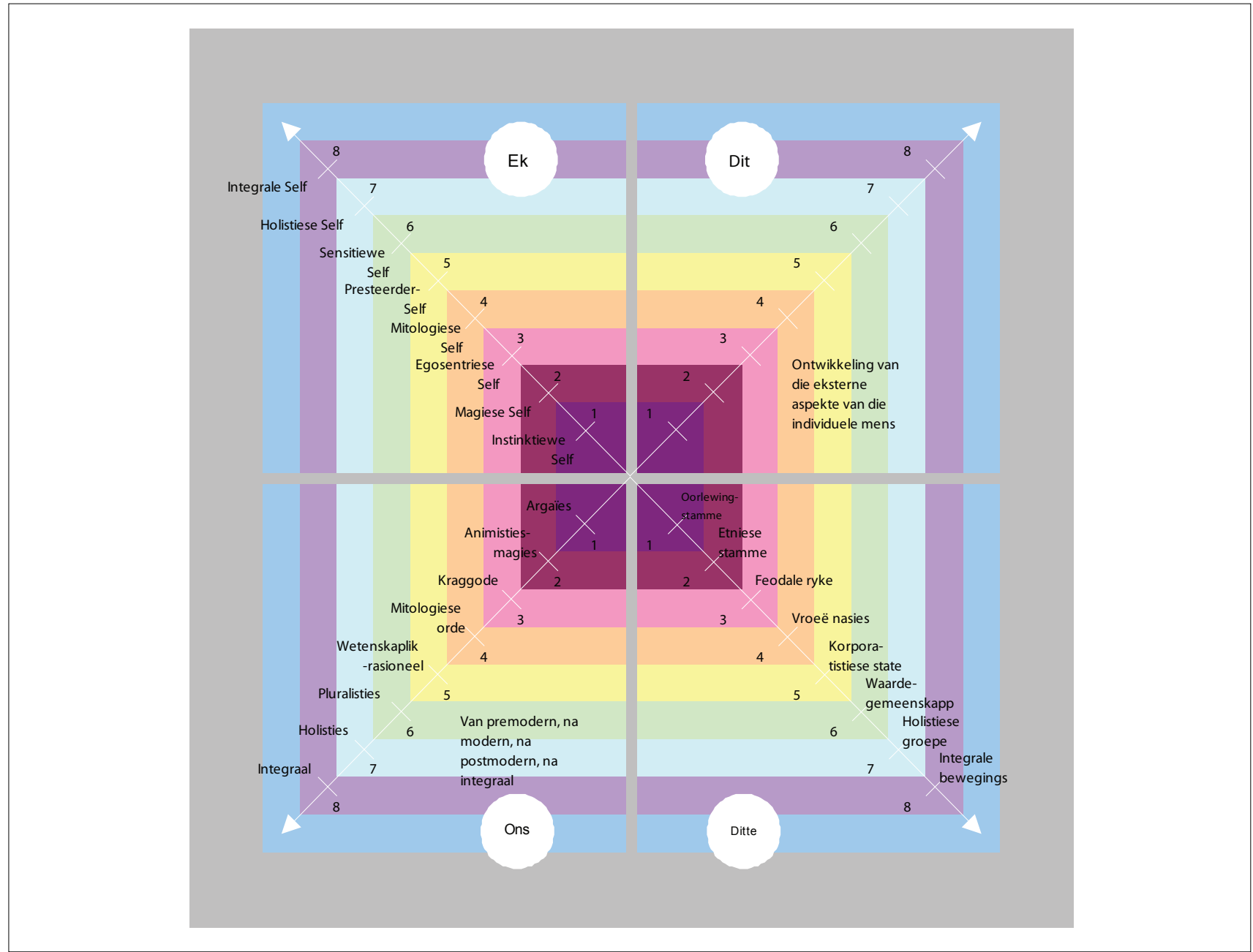

FIGUUR 2

Integrale kwadrante

hê, is belangrik. Soos die artikel later sal aantoon, kan gelowiges op verskeie vlakke bygestaan word. Die ontwikkelingsvlakke wat Wilber gebruik, lê ten grondslag aan hierdie artikel, naamlik argaïes, magies, mities, rasioneel, pluralisties, integraal/holisties en transpersoonlik.

Clare Graves, die ontwikkelaar van Spiral Dynamics, was van die eerste navorsers wat die verskillende vlakke met behulp van kleure aangedui het. Dit het vinnig by almal byval gevind, en dus, ter wille van die teenstand teen hiërargieë, verwys psigoloë na die verskillende vlakke aan die hand van die kleure van die reënboog. Wilber pas die kleure egter ietwat aan: Die eerste of onderste vlak is infrarooi, waarna magenta, rooi, amber, oranje, groen, teaal, turkoois, indigo, violet, ultraviolet en uiteindelik helder lig volg. Wanneer ons die vlakke tot sewe beperk, kry ons die volgende: argaïes (infrarooi), magies (rooi), mities (amber), rasioneel (oranje), pluralisties (groen), integraal/holisties (turkoois) en transpersoonlik (indigo en verder).

Volgens Wilber (1996:3) kan niks lank van God verwyderd bly, of lank van die 'Grondslag van die Lewe', waarbuite niks kan bestaan, geskei wees nie. Die geskiedenis is nie die optekening van individuele of nasionale hoogtepunte nie; as 'n voortdurende beweging/vordering in menslike bewussyn is dit eerder die verhaal van die mens se liefdesverhouding met God. Soos reeds aangetoon, behels dit die beweging van die liggaam, na die verstand, na die siel, en na die Gees. Tog het die mens hiermee 'n probleem, want om God te bereik, moet die 'eie ek' sterf. Wilber verwoord dié dilemma soos volg:
But, at the same time, he is terrified of real transcendence, because transcendence entails the "death" of his isolated and separate-self sense. Because he won't let go of and die to his separate self, he cannot find true and real transcendence, he cannot find that larger fulfillment in integral Wholeness.

(Wilber 1996:16)

As gevolg hiervan vervang mense hulle eenheid met God of Atman met die ego, en in plaas daarvan om een met God te wees, probeer die mens om self God te speel. Wilber noem dit die Atman-projek:

The Atman project is a substitute for Atman, but it also contains a drive to recapture Atman. It is ultimately the Atman project that moves history, moves evolution, and moves the individual psyche.

(Wilber 1996:17)

Voordat die ware Self nie in superbewussyn na vore tree nie, sal die Self altyd met twee dryfvere sit, naamlik (Wilber 1996:17) 'the perpetuation of its own existence (Eros) and the avoidance of all that threatens its dissolution (Thanatos)'. Alle kulturele aktiwiteite en artefakte word aangevuur deur pogings om die dood te ontwyk, en dien dus as plaasvervanger vir die ware lewe. Dalk is dít wat Jesus bedoel het toe hy in Markus 8:36 gesê het: 'Wat help dit ' $n$ mens tog om die hele wêreld as wins te verkry en sy lewe (siel) te verloor.'

Met ál hierdie inligting tot die leser se beskikking sal dié artikel vervolgens die verskillende ontwikkelingsvlakke in die individuele interne kwadrant van nader bekyk. Wilber se siening van die ontwikkelingsverloop het ook intussen verander; hy het van die vlakke saamgevoeg om 'n eenvoudiger kaart te 
teken. Hierdie gedeelte is gegrond op Wilber (2000e:48-53) se uiteensetting van die ontwikkeling van menslike bewussyn in Integral Psychology: Consciousness, Spirit, psychology, therapy, met al die nodige aanpassings.

\section{Argaïes (infrarooi)}

Op hierdie vlak gaan dit volgens Wilber (2000e:48-49) hoofsaaklik om oorlewing ten einde kos, water, warmte en veiligheid te bekom. Mense op dié vlak gebruik instink en gewoontes om te oorleef. Daar bestaan nog geen bewustheid van die onderskeid tussen die Self en die natuur nie. Mense verdeel onderling in oorlewingsbendes om te kan bestaan. Dié vlak kom gewoonlik voor by die eerste menslike gemeenskappe, babas, mense met ouderdomsdemensie, diegene met gevorderde Alzheimersiekte, geestelik versteurdes, straatmense, ensovoorts. Slegs $0,1 \%$ van die wêreldbevolking is op hierdie vlak, en hulle beskik oor $0 \%$ mag.

\section{Magies (rooi)}

Wilber (2000e:49) beskryf die denke in hierdie fase as animisties, met magiese geeste, sowel goed as sleg, wat oor die aarde sweef om seën en vloek uit te deel en deur towerkragte gebeure te bepaal. Mense vorm etniese stamme, en die geeste leef in die voorouers en bind die stam saam. Familiebande bepaal politieke verbintenisse. Dit klink baie holisties, maar is eintlik atomisties - 'daar's 'n naam vir elke kronkel in die rivier, maar geen naam vir die rivier nie'. Dié fase word verteenwoordig deur dolosgooiende sangomavloeke, bloedbeloftes, oeroue wraaksug, gelukbringers, familierituele, magiese etniese geloof en bygeloof. Dit kom meesal in Derdewêreldgebiede voor, maar ook by bendes, sportspanne en 'korporatiewe stamme'. Diegene in hierdie fase maak ongeveer $10 \%$ van die wêreldbevolking uit, en beskik oor 1\% van die mag. Wilber (2006:92) noem dat hierdie persone Jesus as ' $\mathrm{n}$ persoonlike Verlosser beleef wat wonderwerke kan verrig om die wêreld te verander ten einde 'my' persoonlike behoeftes en begeertes te bevredig. Omdat hierdie vlak prekonvensioneel en egosentries is, gee Jesus, die 'towenaar', net vir 'my' om.

\section{Mitologies (amber)}

Aanvanklik het Wilber (2000e:49) hierdie fase of vlak in twee verdeel, naamlik die rooi magtige gode, en die blou konformistiese voorskrif. Later het hy dit egter gekombineer. Dit behels eerstens die rooi fase van die ontvouing van die Self wat nie meer deel uitmaak van die stam nie. Dié vlak is magtig, impulsief, egosentries en heldhaftig. Mitiese geeste, drake, gedrogte en magtige mense word hier vereer. Feodale heersers wat hulle onderdane in ruil vir gehoorsaamheid en arbeid beskerm, geniet groot aansien. Wilber (2006:92) noem dat Jesus op hierdie vlak as die Ewige Waarheidsdraer beleef word. Hierdie fase is absolutisties in sy geloofsuitsprake, en daarom sal mense in die 'Woord van God' glo, of vir ewig in die hel brand. Omdat hierdie vlak etnosentries is, sal slegs diegene wat in Jesus as hulle persoonlike Verlosser glo, gered word. Diegene op hierdie vlak is byvoorbeeld die rebelse jeug, diegene met baanbrekersgees, feodale koninkryke, epiese helde, James Bond-skurke, huursoldate en wilde rocksterre. Uit hierdie fase spruit die konformistiese vlak, waar die lewe betekenis, rigting en doel kry, en waarvan die uitkoms deur die Almagtige Ander bepaal word. Hierdie Regverdige Orde dwing 'n gedragskode wat op absolute beginsels van reg en verkeerd berus op ander af. Oortreding van dié kode en wette het rampspoedige, miskien selfs ewig verdoemende, gevolge. Hier bestaan daar ' $n$ rigiede, sosiale, paternalistiese hiërargie wat ander deur skuldgevoelens beheer. Dié ontwikkelingsvlak kom onder puriteins Amerika; Confucianisme China; Islamitiese, Joodse en Christelike fundamentaliste; en die sogenaamde 'morele meerderheid' voor. Die groep is groter as die stam of familie van die vorige fase. Gesamentlik verteenwoordig mense op dié vlak $60 \%$ van die wêreldbevolking, wat oor 35\% van die mag beskik.

\section{Rasioneel (oranje)}

Wilber (2000e:50) het dié fase aanvanklik 'Orange: Scientific
Achievement' genoem, en wys daarop dat die Self op hierdie vlak van die 'kuddementaliteit' van die vorige vlakke ontsnap, en waarheid en betekenis op individualistiese gronde soek. Op hierdie vlak is die wêreld rasioneel, 'n goed geoliede masjien, met natuurwette wat geleer, bemeester en na willekeur gemanipuleer word. In dié fase is prestasie, veral materialistiese voordele, baie belangrik. Wetenskaplike wette beheer die politiek, die ekonomie en menslike handelinge. Sake-ondernemings staan aan die stuur van alle besluite in die samelewing. Wilber (2005:35) staan krities teenoor mitologiese teoloë wat verbete aan hulle prerasionele en premoderne idees vasklou, en wat sekularisasie steeds as die oersonde beskou: 'There is more Spirit in reason's denial of the mythic God than there is in myth's affirmation of that God'. Modernisme tref die onderskeid tussen die kulturele sfere van kuns (skoonheid), moraliteit (goedheid) en wetenskap (waarheid); of die self, kultuur en natuur. Wetenskap is die objektiewe eksterne werklikheid; kuns is die persoonlike en subjektiewe; terwyl moraliteit die groep se kollektiewe subjektiwiteit verteenwoordig.

Die wetenskap het die wedloop gewen, en het die kerk uitgedaag om wetenskaplike bewyse vir hulle geloof te lewer. Op die rasionele vlak word Jesus dus as ' $n$ vermenslikte figuur beleef nog steeds volledig goddelik én ten volle mens, maar nou meer menslik op ' $n$ meer aanvaarbare manier, as 'n leermeester van die universele liefde van 'n deïstiese God. Beskryf geloof in Jesus op hierdie vlak soos volg:

Because this stage is the beginning of the postconventional and worldcentric stages, this is also the first of the stages of development that can find salvation through Christ Jesus but also allow that others might find equal salvation though a different path.

Wilber (2006:92)

Hierdie siening van die werklikheid kom by die Verligting voor, in Ayn Rand se Atlas Shrugged, in Wallstraat, onder die opkomende middelklas wêreldwyd, in die skoonheids- en modebedryf, in trofeejag, en by materialiste. Dié groep maak ongeveer 30\% van die wêreldbevolking uit, maar besit ongeveer $50 \%$ van die mag.

\section{Pluralisties (groen)}

In The marriage of sense and soul bied Wilber (2000d:183-199) 'n omvattende uiteensetting van postmodernisme, maar vir die doel van hierdie artikel word die bespreking oor postmodernisme tot Wilber (2000e:50-51, 162-173) se integrale psigologie beperk. Postmoderniteit poog om moderniteit op verskillende maniere te reduseer en teen te werk, met ander woorde om die dissosiale tussen kuns, wetenskap en kultuur tot net die wetenskap in te kort. Wilber (2000e:162) noem die reduksie van modernisme 'flatland', en beweer dat postmodernisme gekenmerk word deur dit wat postmodernisme verwerp (eerder as deur dit wat postmodernisme verteenwoordig). Postmodernisme verwerp fondamentalisme, essensialisme, transendentalisme, rasionaliteit en verteenwoordigende kennis - 'The reject grand narratives, metanarratives, and big pictures of any variety. They reject realism, final vocabularies, and canonical description.

Wilber (2000e:50) noem hierdie fase Groen: Sensitiewe Self. Die menslike gees moet hiervolgens vrygemaak word van hebsug, dogma en absolute sekerhede. Gevoel en versorging oorheers koue rasionaliteit, en daar is 'n intuïtiewe sorgsaamheid teenoor die natuur, Gaia en die lewe. Diegene op hierdie ontwikkelingsvlak is voorts teen hiërargieë gekant, en dink eerder in laterale verbindings. Hulle konsentreer op verhoudings waarin dialoog die botoon voer. Hierdie paradigma word dikwels 'pluralistiese relativisme' genoem. Volgens Wilber (2000e:50) is dié vlak tipies van diep ekologie, postmoderniteit, Nederlandse idealisme, Kanadese gesondheidsorg, humanistiese psigologie, bevrydingsteologie, die Wêreldraad van Kerke, Greenpeace, diereregtegroepe, ekofeminisme, postkolonialisme, Foucault/ Derrida, politieke korrektheid, menseregte en ekopsigologie. Hierdie groep maak 10\% van die wêreldbevolking uit, en besit ongeveer $15 \%$ van die mag. 
Wilber (2000e:51) voer aan dat mense met hierdie soort tweedelaag-bewussyn sowel vertikaal as horisontaal dink, en sowel hiërargieë as heterargieë gebruik. Hy beweer dat hulle die eerstes is wat die 'groter prentjie' sien, en (Wilber 2000e:51) 'vividly grasp the entire spectrum of interior development, and thus see that each level, each meme, each wave is crucially important for the health of the overall spiral'. Hierdie perspektief ontwikkel egter slegs met oorpeinsing. Daarom sal die volgende vlakke vir die leser soms as esoteriese onsinnighede voorkom, maar maak dit wél deel uit van die ontwikkeling van die menslike bewussyn of geloof.

\section{Integraal/holisties (turkoois)}

Wilber, Patten, Leonard en Morelli (2008:96) meen dat diegene met 'n turkoois-wêreldbeskouing op ' $n$ dieper vlak besef dat alle idees konstruksies is - selfs die eie sin van die Self. Mense op hierdie vlak besef dat daar outomatiese beperkings op alle konseptuele prosesse is. Hulle begin ontwikkel simpatie - nie vir enige bepaalde perspektief nie, maar 'with the space in which all perspectives arise'. Diegene op hierdie vlak is daartoe in staat om met behulp van ' $n$ verskeidenheid aanvullende gereedskap die inherente geheimenisse van ervaring te vertolk. Hoewel persone in die turkooisfase die deugde van alle ontwikkelingsfases kan waardeer, is hulle nie blind vir hulle eie tekortkominge nie. Individue op hierdie vlak vind dit moeilik om eendersdenkendes te ontmoet wat hulle verstaan, en wat simpatie het met hulle omvattende dimensionaliteit en intense bewustheid. Volgens Wilber et al. (2008:96) begin selfs alledaagse denkprosesse om alle mense, lewende wesens en lewende sisteme in te sluit: 'They become even more interested and committed to awakening and to rendering service to others and the world.' Wilber wys daarop dat hierdie beweging na ' $n$ hoër bewussyn ' $n$ breër identiteit na vore bring:

[a]nd the soul and God enter an even deeper interior marriage, which discloses at its summit a divine union of Soul and Spirit, a union prior to any of its manifestations as matter or life or mind, a union that outshines any conceivable nature, here or anywhere else.

(Wilber 2000a:301)

\section{Transpersoonlik (indigo)}

Die volgende vlakke se konkrete inhoud vervaag, omdat daar nie juis ' $n$ oorvloed mense is wat hiervan kan getuig nie. Wilber et al. $(2008: 96,97)$ bestempel die indigo-fase as die eerste werklik transpersoonlike vlak, wat beteken dat 'n persoonlike selfbewussyn die persoonlike te bowe gaan. 'It goes beyond an exclusive identification with the personality, while including the personality in its signature uniqueness. By its very nature Indigo worldview begins to transcend the separation of the subject from the object.' Hierdie vlak word ook deur 'n verskuiwing na ' $n$ hoogs intuïtiewe, buigsame en vloeiende verhouding met ervaring gekenmerk. Wilber et al. (2008:97) meen daar is ' $n$ belangrike verskil tussen die turkoois- en indigo-fase: Diegene in die turkoois-fase bedink alles met behulp van 'n oorkoepelende visie, terwyl diegene op die indigo-vlak die geheel sien sonder om alles te probeer verbind. Nóg ' $n$ kenmerk van die indigo-fase is soos volg:

Systemic and transpersonal wholes are simply apparent, including ecological, political, and cultural wholes that transcend the individual. The personal self-sense opens into these larger systems, identifies with them, and often feels a profound sense of openness, particularly in the waking state and gross realm

(Wilber et al. 2008:97)

Persone op die indigo-vlak sien nie nét deur die ego-Self nie; hulle laat vaar die ego-Self as die enkele middel- en verwysingspunt van waar hulle nog altyd die komplekse dans tussen verhoudings, prosesse en ervarings beleef het. Dít verminder die spanning of stres tussen individualiteit en onderlinge verbintenisse. Die lewe word aan die hand van ' $n$ radikale, buigsame tydskaal beskou wat van minute, tot jare, tot leeftye, tot millennia, tot diepe tyd, tot radikale tydloosheid, of tot pure ewigheid strek.

\section{NUWE HORISONNE}

In navolging van Wilber voer Jim Marion (2000) die ontwikkeling van die menslike bewussyn verder, en gebruik hy Johannes van die Kruis se meesterwerk Dark night of the soul (Peers 2005) om die oorgange na die volgende vlakke te verduidelik.

Hier gaan dit nie soseer daaroor dat daar géén duidelikheid oor die waarheid bestaan nie. Inteendeel, baie waarhede kan nou juis baie duidelik gesien word. Marion (2000:118) noem egter dat daar tog sekere aspekte van die ontwikkelingsvlakke is wat raaiselagtig bly: 'Awe, wonder, and amazement constantly occur in these realms and are indeed the fuel that keeps us striving ever onward to God, despite the terrific dangers and obstacles.' Die dood en hergeboorte van die Donker Nag van die Siel onderskei mense wat dink dat hulle gewone sterflinge is, van diegene wat besef dat hulle goddelik en onsterflik is. Die mens betree die Donker Nag van die Siel in die oortuiging dat hy sondig en gevalle is en verlossing nodig het, en kom daaruit in die wete dat hy vir ewig sondeloos en gered is. Herverskyning en hergeboorte vanuit die Donker Nag van die Siel oorwin sowel die dood as sonde, soos Paulus in 1 Korintiërs 15:55-56 getuig.

Marion (2000:119-125) brei hierop uit om die vraag op baie mense se lippe te beantwoord: Hoekom moet die gelowige wat tot hier gevorder het die lyding van die doop deur vuur en die Gees ondergaan? Daar is vier redes: Die eerste is intellektueel, en gaan oor die besef van wie ons werklik is. Die tweede rede is die reiniging van ons emosies, wat die menslikste rede is. Marion stel dit só:

All of us have incarnated here for one reason only; to learn to love, to love as Jesus did. This cannot be done as long as our emotional bodies are not thoroughly purified by the death and rebirth of the Dark Night.

(Marion 2000:120)

Die derde rede vir dié lyding is dat ons huidige persoonlikheid nie die enigste beliggaamde persoonlikheid is wat ons siele geskep het nie. Daar was voorheen baie ander persoonlikhede, en die lyding is dus as gevolg van hierdie ongesiene dele van die siel. Die vierde rede vir die psigiese lyding is transpersoonlik. Volgens Marion (2000:123) is die lig en donker in elke mens aan ander verbind: 'The Christian in the Dark Night like Jesus on the Cross, is allowed to participate in the redemptive work of the Christ', en in dié verband verwys Marion die leser na Kolossense 1:24, waar Paulus die volgende sê:

Ek is nou bly oor al die lyding wat ek ter wille van julle moet verduur, want die vervolging van Christus het nog nie geëindig nie. Ek verduur my deel daarvan ter wille van sy liggaam, die kerk.

(Kolossense 1:24)

Wilber noem dié vlak die kousale fase. Op die subtiele vlak verenig die siel en God, en:

[I]n the causal level, the Soul and God are both transcended in the prior identity of Godhead, or pure formless awareness, pure consciousness as such, the pure Self as pure Spirit (Atman = Brahman).

(Wilber 2000b:309)

Marion (2000:183-195) noem die kousale fase die 'Christusbewussyn'. Op hierdie vlak vereenselwig die Christen hom/haar met sy/haar ware Christus-Self, wat as 'n geestelike eenheid met God die Skepper gesien word. Op hierdie vlak kan die gelowige waarlik sê: 'Dis nie ék wat lewe nie, maar Christus wat in my leef.' Die persoon met Christusbewussyn sien alle ander mense as die Christus, en tree dieselfde teenoor almal op. Dít is die vlak van ware Christelike liefde, waar die spirituele liefde identies is aan wat die Boeddhistiese meesters ware barmhartigheid noem. Die persoon met Christusbewussyn is vry van neurotiese projeksies en emosionele verslawing, en is in staat om slegs in die hede te lewe - merkwaardig objektief 
teenoor alledaagse probleme en angste. Marion (2000:183) beskryf hierdie soort kommunikasie met God soos volg: 'One is able to commune silently with God, now seen as the Great Void or Mother Creator within. From which all creation and creativity arises.' Dit is die eerste vlak van menslike bewussyn wat nie as ' $\mathrm{n}$ menslike persoonlikheid funksioneer nie, maar as 'n verwerklikte goddelikheid. Hier bestaan daar innerlike vrede, want die binneste is nie meer onderverdeel nie. Hierdie fase kan lank duur, en die geestelike pad na die koninkryk van God is lank en moeisaam. Dit is hoekom Christene vroeg moet begin, en hard moet werk. Daar is geen terugkyk- of omdraaikans nie.

Wilber beskou nie die kousale as die spreekwoordelike 'laaste woord' nie:

When one breaks through the causal absorption in pure unmanifest and unborn Spirit, the entire manifest world arises once again but this time as a perfect expression of Spirit and as Spirit. The Formless and the entire world of manifest Form - pure Emptiness and the whole Kosmos - are seen to be not-two (or nondual). The Witness is seen to be everything that is witnessed.

(Wilber 2000b:317)

Wanneer alle dinge net God is, dan is daar geen dinge nie, en geen God nie, maar slegs dít. Daar is dan niemand wat waarneem nie, en niks om waar te neem nie. Wilber (2000b:318) bestempel dit as die radikale einde van alle egosentrisme, geosentrisme, alle biosentrisme, alle sosiosentrisme, en alle teosentrisme, want dit is die einde van alle sentrisme.

Marion (2000:197-214) beskryf hierdie niedualistiese bewussyn as die opvaar na die koninkryk van die hemel, wat die einddoel van sowel die Christelike geestelike weg as al die groot nadenkende godsdienste is. In die Christelike NuweTestamentiese mitologie word die toegang tot die niedualistiese vlak van die koninkryk van God deur die hemelvaart van Jesus gesimboliseer.

Die niedualistiese koninkryk van God is die boodskap wat Jesus verkondig het. Indien die kousale vlak deur vrede gekenmerk word, is saligheid en vreugde die eienskappe van die niedualistiese fase. Marion (2000:198) voer twee redes aan waarom hierdie fase as die tweede vlak van goddelikheid beskou word: Eerstens moet gelowiges deur al die vorige fases beweeg voordat hulle tot hier kan vorder; en tweedens het dié vlak se energievibrasies, soos wat dit deur die liggaam én die verstand beleef word, 'n hoër frekwensie as die ander vlakke. Die mens moet voorts ook van alle polariteite afstand doen. Die gelowige moet 'van die pad afval' om hier te kom, en moet ophou om die spirituele weg as 'n pad te beskou. Marion (2000:198-199) beskryf dit só: 'We have to once and for all simply surrender to what has been all along: our divine identity now consciously realized and seen.' Hierdie vlak is nie werklik 'n vlak nie, maar eerder die goddelike grondslag van bestaan waarop alle vorige vlakke gegrond is. Hierdie vlak is dus nie bó die Christusbewussynvlak nie, maar eerder ' $n$ vervulling daarvan (Joh. 10:30,38). Op die niedualistiese vlak van die menslike bewussyn verdwyn alle dualiteite. Dít impliseer die verwydering van ' $\mathrm{n}$ afsonderlike subjek en objek; die versmelting van die twee in ons bewussyn. Die siener word die een wat gesien word, sowel as die oog wat sien. Christus en die Vader word nou nie as twee nie, maar as een waargeneem. Die Christus, en enigeen wat Jesus tot op hierdie vlak as die Christus gevolg het, staan nie langer in die ek-U-verhouding met God nie, maar in 'n Ek-Ek eenheid - 'n suiwer subjektiwiteit sonder ' $n$ objek.

Meister Eckhart het in dié verband gelowiges aangeraai om hulle van alles te ontledig:

That is to say, empty yourself of your ego and empty yourself of all things and of all that you are in yourself and consider yourself as what you are in God. God is a being beyond being and a nothingness beyond being. Therefore, be still and do not flinch from this emptiness.

(Fox 1980:104, 178, 242)
Die ontwikkeling van die menslike bewussyn is ongetwyfeld ' $\mathrm{n}$ moeilike pad om te volg. Die roete na die mitologiese en selfs die rasionele vlakke verloop dikwels sonder inspanning, maar sodra die mens van die pluralistiese na die postrasionele vlakke wil beweeg, is geestelike oefening nodig. Dit is hiér waar die pastor met behulp van Ken Wilber se AQAL-teorie 'n groot bydrae to die begeleiding van lidmate in hulle geestelike oefening en dus ook hulle bewussynsontwikkeling kan lewer.

\section{LITERATUURVERWYSINGS}

Amour, E.T., 2006, 'Towards an elemental theology: A constructive proposal', in D.B. Ray (red.), Theology that matters, pp. 42-57, Fortress Press, Minneapolis.

Fox, M. (vertl), 1980, Breakthrough: Meister Eckhart's creation spirituality in new Translation, deur Meister Eckhart, Image Books, Garden City, New York.

Peers, E.A. (vertl), 2005, Dark night of the soul, deur Johannes van die Kruis, Image Book, Doubleday, New York.

Lovejoy, A., 1964, The Great Chain of Being, Harvard University Press, Cambridge.

Marion, J., 2000, Putting on the mind of Christ: The inner work of Christian spirituality, Hampton Roads Publishing Company Inc., Charlottesville.

Nolte, S.P., 2007, 'Pastors as gewonde genesers: Emosionele intelligensie en pastoraat Pastors as wounded healers: Emotional intelligence and Counseling', ongepubliseerde PhD-verhandeling, Universiteit van Pretoria, Pretoria.

Reynolds, B., 2004, Embracing reality: The integral vision of Ken Wilber, Penguin Group, New York.

Reynolds, B., 2006, Where's Wilber at? Ken Wilber's Integral vision in the new millennium, Paragon House, St. Paul.

Rumscheidt, B. \& M. (vertl), 2001, The silent cry: Mysticism and resistance, deur D. Soelle, Augsburg Fortress, Minneapolis.

Teasdale, W., 1999, The mystic heart: Discovering a universal spirituality in the world's religions, New World Library, Novato, Kalifornië.

Tzu, L., 2007, Tao te Ching, Shambhala, Boston/Londen.

Wilber, K., 1996, Up from Eden: A transpersonal view of human evolution, The Theosophical Publishing House Wheaton, Illinois.

Wilber, K., 2000a, The collected works of Ken Wilber Vol. 5: Grace and Grit, Shambhala, Boston/Londen.

Wilber, K., 2000b, The collected works of Ken Wilber Vol. 6: Sex, ecology, spirituality, Shambhala, Boston/Londen.

Wilber, K., 2000c, The collected works of Ken Wilber Vol. 7: The eye of Spirit, Shambhala, Boston/Londen.

Wilber, K., 2000d, The collected works of Ken Wilber Vol. 8: The marriage of sense and Soul, One Taste, Shambhala, Boston/ Londen.

Wilber, K., 2000e, Integral Psychology: Consciousness, Spirit, psychology, therapy, Shambhala, Boston/Londen.

Wilber, K., 2000f, A theory of everything: An integral vision for business, politics, science and spirituality, Shambhala, Boston/ Londen.

Wilber, K., 2001, Eye to eye: The quest for a new paradigm, Shambhala, Boston/Londen.

Wilber, K., 2005, A sociable God: Towards a new understanding of religion, Shambhala, Boston/Londen.

Wilber, K., 2006, Integral spirituality: A startling new role for religion in the modern and postmodern world, Integral Books, Boston/Londen.

Wilber, K., Patten, T., Leonard, A. \& Morelli, M., 2008, Integral Life Practice: The 21st century blueprint for physical health, emotional balance, mental clarity, and spiritual awakening, Integral Books, Boston/Londen. 